Original Research Paper

\title{
Bioaccumulation and Tissue Partitioning of Endosulfan by the Red Hybrid Tilapia
}

\author{
Dwight E. Robinson \\ Department of Life Science, University of West Indies, Mona, Kingston 7, Jamaica
}

Article history

Received: 24-02-2015

Revised: 03-05-2015

Accepted: 20-06-2015

\begin{abstract}
The frequent use of endosulfan in agricultural activity on steep slopes in Jamaica and subsequent contamination of rivers by the residues resulted in a need to assess the levels of bioaccumulation of sub-lethal doses of the insecticide in river fauna using Tilapia fish as a test subject. Bioconcentration of $\alpha$ - and $\beta$-endosulfan by the Red Hybrid Tilapia, from $0.0075 \mathrm{mg} \mathrm{L}^{-1}$ in the surrounding water, reached a peak $(0.578 \mathrm{ppb}$ and 0.442 $\mathrm{ppb}$, respectively) in one to four hours but fluctuated during the rest of the 72$\mathrm{h}$ observation period. A similar pattern of bioaccumulation was recorded when the fish were exposed to $0.015 \mathrm{mg} \mathrm{L}^{-1}$, except that the peak bioaccumulation of $\alpha$ - and $\beta$-isomers after one hour of exposure were 0.54 and $0.44 \mathrm{mg} \mathrm{L}^{-1}$, respectively. The contaminated fish (from 24-h exposure to $0.015 \mathrm{mg} \mathrm{L}^{-1}$ ) eliminated only 18 to $31 \%$ of endosulfan residues after $24 \mathrm{~h}$ and 26 to $39 \%$ after $72-\mathrm{h}$ exposure to uncontaminated water. During the process of bioconcentration, endosulfan was metabolized to endosulfan lactone and sulfate; the degradation was more during the elimination process when exposed to clean water. Maximum amounts of $\alpha$-and $\beta$-endosulfan and their metabolites were partitioned in gonads $>$ liver $>$ gills $>$ skin/muscle/bone.
\end{abstract}

Keywords: Endosulfan, Bioaccumulation, Tilapia

\section{Introduction}

The use of pesticides in agricultural production systems has resulted in the contamination of water resources in several regions of the world (Chopra et al., 2011; Shahpoury et al., 2013). The risk of such contamination may be even greater in small Caribbean states where agricultural activity on steep slopes, the intensity and pattern of rainfall, unsuitable agronomic practices and the close proximity of stream and rivers to agricultural activity often favour the run-off of pesticide residues to rivers and streams (Mansingh et al., 2003). Mansingh et al. (1997; 2003) has reported extensively on the contamination of Jamaican and coastal waters by pesticides. Up until recently, endosulfan was used extensively against the coffee berry borer, Hypothenemus hampei Ferrari, in the Blue Mountain and highlands of Jamaica where most rivers originate and it is therefore not surprising that its residues were detected in many wells and springs, rivers, coastal waters and aquatic fauna in Jamaica (Robinson and Mansingh, 1999; Witter et al., 1999).
Chronic and acute toxicity of pesticide residues is believed to be responsible for the general decline of rivers and coastal fishing in the Caribbean. However, for environmental risk assessment, basic data on the fate of residues in the local environment, their partitioning between aqueous/solid/organic phases and impact on non-target organisms is essential (Rand, 1995). The fate of endosulfan under controlled and field conditions in Jamaica is well documented (Singh et al., 1991; Robinson et al., 1997), but not its ecotoxicity potential.

The present study was therefore designed to investigate the bioconcentration and tissue partitioning of sub-lethal concentrations of endosulfan in the hybrid Red Tilapia fish.

\section{Materials and Methods}

\section{The Fish and its Exposure to Endosulfan}

Sexually mature individuals of the Red Hybrid tilapia (8-9 cm long) were obtained from a commercial farm and held in aerated glass aquaria for at least two weeks 
for acclimatization. Fish meal was provided daily and water was changed every three days.

Six $20 \mathrm{~L}$ glass aquaria with $18 \mathrm{~L}$ water were aerated for $24 \mathrm{~h}$ before the required amount of Thiodan 35EC (supplied by Hoescht, Germany; purity checked by GC was $33.75 \%$ ) was added to the experimental tanks and water agitated manually for $5 \mathrm{~min}$. About $30 \mathrm{~min}$ later, 18 fishes were introduced into each of the experimental and control aquarium. Fish were transferred to freshly prepared aquaria, with the same concentration of endosulfan as before; the half-life for the dissipation of $\alpha$-and $\beta$-endosulfan from water being 27.5 and 23.5 days, respectively (Robinson et al., 1997). The fish were not fed for the first three days, but the pellets were provided everyday thereafter, in small amount to ensure as little left-over as possible. Each experiment was conducted in triplicate.

\section{Bioconcentration, Tissue Partitioning and Elimination}

Fishes were exposed to 0.0075 and $0.015 \mathrm{mg} \mathrm{L}^{-1}$ of endosulfan for three days and samples of three individuals from each replicate were taken out, along with $100 \mathrm{~mL}$ of water at 1, 4, 8, 12, 24, 48 and $72 \mathrm{~h}$ after the exposure. The fish samples were rinsed twice with 15 $\mathrm{mL}$ distilled water, wiped with paper towel, weighed and frozen until residue extraction.

For determining the tissue partitioning, 10 fish in each of the three replicates were exposed to $0.015 \mathrm{mg}$ $\mathrm{L}^{-1}$ of endosulfan and $24 \mathrm{~h}$ later, they were removed, rinsed in water, blotted dry and dissected to remove the different tissues. Each tissue/organ from the fish in a replicate were pooled, weighed and frozen for residue extraction at a later date.

The rate of elimination of endosulfan was studied by first exposing 18 fishes each in three replicates to 0.015 $\mathrm{mg} \mathrm{L}^{-1}$ of the insecticide for $24 \mathrm{~h}$, removing them with a net to two successive distilled water tanks for 30 seconds each before transferring them to $20 \mathrm{~L}$ aquaria with uncontaminated water. At regular intervals, fish and water samples were collected and frozen, as described earlier.

\section{Residue Analysis}

All chemicals used in the present study were chromatographic grade (supplied by Fisher Scientific Co.) or redistilled and the purity checked by Gas Chromatography (GC). Glassware were always rinsed with hexane and checked occasionally for contamination.

The extraction of residues from tissues and water was done according to the UNEP (1991) methodology, as described by Robinson and Mansingh (1999). Frozen fish samples were thawed, chopped, mixed with $100 \mathrm{~g}$ anhydrous sodium sulfate and $150 \mathrm{~mL}$ Petroleum Ether (PE) and blended at high speed for two minutes. The PE homogenate was suction-filtered through a Whatman \# 1 filter paper in a Buckner funnel; the residue and the paper were blended twice in $100 \mathrm{~mL}$ PE each and filtered along with the homogenizer cup washings. The combined filtrate was concentrated in a rotor-evaporator and then partitioned in acetonitrile.

A Hewlett-Packard HP 5890 Series II gas chromatograph equipped with a ${ }^{63} \mathrm{Ni}-\mathrm{ECD}$ was used to detect endosulfan. Analytical conditions were a $30 \mathrm{~m}$ HP-1 capillary column; carrier gas, nitrogen, at a flow rate of $10-15 \mathrm{~mL} \mathrm{~min}^{-1}$; temperature settings: Column $230^{\circ} \mathrm{C}$, injector $280^{\circ} \mathrm{C}$ and detector $300^{\circ} \mathrm{C}$. The detection limit, determined by the peaks of the solvent baseline \pm s.d. $\times 5$, was $0.001 \mathrm{ng}$. Recovery of $\alpha$ - and $\beta$-endosulfan, determined by fortified samples with the standard concentration was $89 \pm 3.6$ and $87 \pm 2.9 \%$, respectively from the tissues and $93 \pm 1.5$ and $92 \pm 1.2 \%$, respectively, from water.

\section{Results}

\section{Bioconcentration and Tissue Partitioning}

\section{The Uptake}

The uptake of both $\alpha$ - and $\beta$-endosulfan from both concentrations $\left(0.0075\right.$ and $\left.0.015 \mathrm{mg} \mathrm{L}^{-1}\right)$ was the fastest during the first hour of exposure to non-lethal concentration of the insecticide (Fig. 1). For the first 24 $h$, the levels of $\alpha$-endosulfan remained fairly constant as it fluctuated insignificantly $(\mathrm{P}=0.248)$ between $0.52 \pm 0.055$ and $0.58 \pm 0.012 \mu \mathrm{g} \mathrm{g}^{-1}$; thereafter, it declined slightly but significantly $(\mathrm{P}=0.047)$ to $0.453 \pm 0.099 \mu \mathrm{g}$ $\mathrm{g}^{-\mathrm{P}}$ at $48 \mathrm{~h}$, but increased insignificantly $(\mathrm{P}=0.719)$ during the next $24 \mathrm{~h}$.

ß-endosulfan levels in the fish declined significantly $(\mathrm{P}=0.007)$ from about $0.44 \pm 0.010 \mu \mathrm{g} \mathrm{g}^{-1}$ after $1 \mathrm{~h}$ to $0.37 \pm 0.030 \mu \mathrm{g} \mathrm{g}^{-1}$ in $4-8 \mathrm{~h}$ and to $0.31 \pm 0.067$ at 12 and $24 \mathrm{~h}$. During the next $24 \mathrm{~h}$, these levels increased insignificantly $(\mathrm{P}=0.207)$ to about $0.37 \pm 0.036 \mu \mathrm{g} \mathrm{g}$ before declining to about $0.34 \pm 0.090 \mu \mathrm{g} \mathrm{g}^{-1}$ at $72 \mathrm{~h}$ of exposure. No significant depletion of the residues nor any metabolite was detected in the aquaria water, the concentration remaining at $0.005 \pm 0.0005$ and $0.0075 \pm 0.0005 \mathrm{mg} \mathrm{L}^{-1}$ throughout the 3-day period, after which the water was replaced.

\section{Degradation}

The process of bioconcentration was associated with the degradation of the insecticide into endosulfan lactone and endosulfan sulfate (Fig. 2). The metabolites were first detected at $4 \mathrm{~h}$ of exposure to the insecticide when their concentrations were the highest than at any other time in the $72 \mathrm{~h}$ experiment. Endosulfan lactone levels declined significantly $(\mathrm{P}=0.038)$ from about $0.52 \pm 0.033$ $\mu \mathrm{g} \mathrm{g}^{-1}$ at $4 \mathrm{~h}$ to about $0.45 \pm 0.042 \mu \mathrm{g} \mathrm{g}^{-1}$ at 8 and $12 \mathrm{~h}$ and again to $0.38 \pm 0.068 \mu \mathrm{g} \mathrm{g}^{-1}$ at $24 \mathrm{~h}$, but fluctuated insignificantly $(\mathrm{P}=0.172)$ thereafter. 


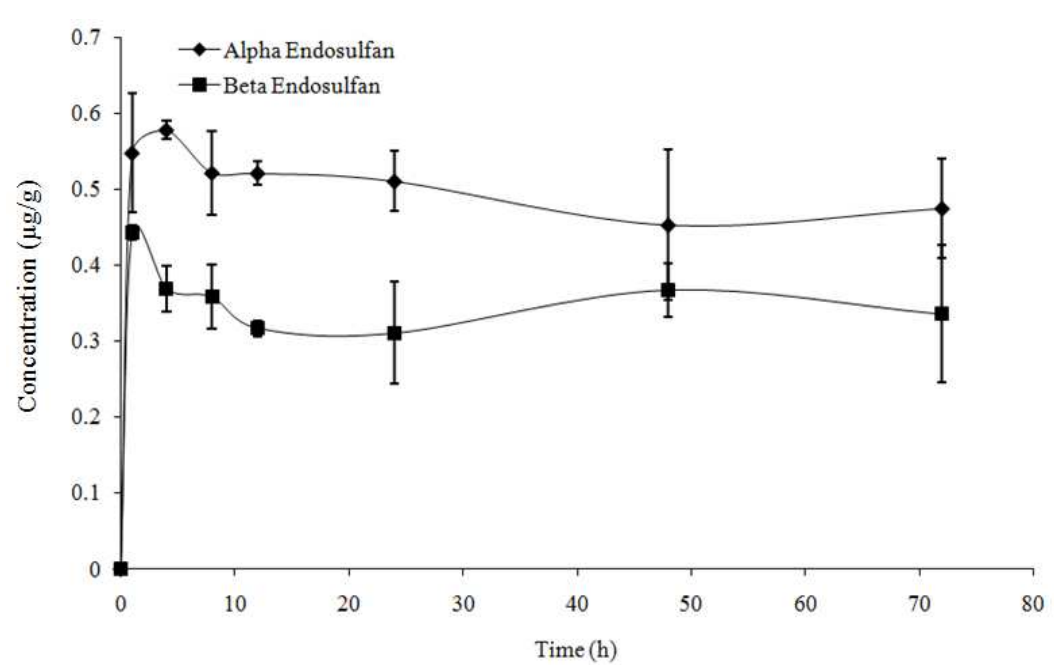

Fig. 1. The accumulation of $\alpha$ - and $\beta$-endosulfan by Tilapia from surrounding water containing approximately $0.0075 \mathrm{mg} / \mathrm{L}$ of endosulfan

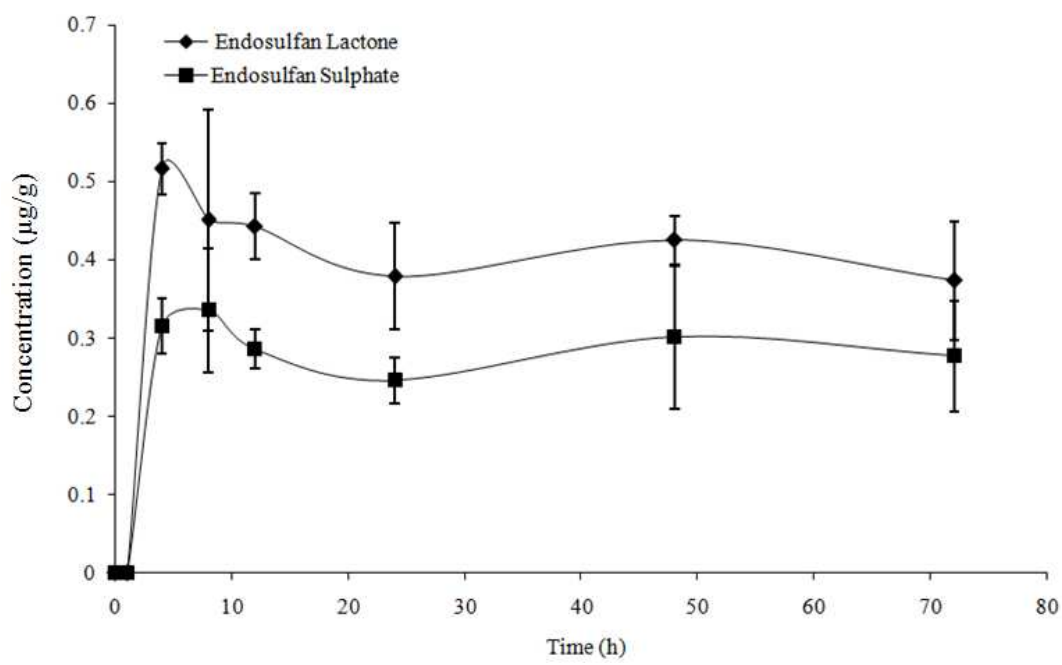

Fig. 2. The formation of endosulfan lactone and endosulfan sulfate by Tilapia exposed to approximately $0.0075 \mathrm{mg} / \mathrm{L}$ of endosulfan for $72 \mathrm{~h}$

\section{Elimination}

When the contaminated fish were transferred to clean water, the rate and pattern of elimination of $\alpha$ - and $\beta$ endosulfan were almost similar (Fig. 3). The levels of $\alpha-$ isomer $\left(0.65 \pm 0.066-0.62 \pm 0.021 \mu \mathrm{gg}^{-1}\right) \quad$ changed insignificantly $(\mathrm{P}=0.092)$ during the first $8 \mathrm{~h}$ but declined significantly $(\mathrm{P}=0.022)$ to $0.55 \pm 0.023 \mu \mathrm{g} \mathrm{g}^{-1}$ at $24 \mathrm{~h}$ and $0.48 \pm 0.039 \mu \mathrm{g} \mathrm{g}^{-1}$ at $72 \mathrm{~h}$. Likewise, the $\beta$ isomer also declined gradually from about $0.56 \pm 0.061$ $\mu \mathrm{g} \mathrm{g}^{-1}$ at $1 \mathrm{~h}$ to $0.43 \pm 0.017 \mu \mathrm{g} \mathrm{g}^{-1}$ at $12 \mathrm{~h}$ and fluctuated only slightly for the next $36 \mathrm{~h}$ before declining significantly $(\mathrm{P}=0.014)$ at $72 \mathrm{~h}$ to $0.35 \pm 0.013 \mu \mathrm{g} \mathrm{g}^{-1}$.

The concentrations of endosulfan lactone and sulfate rose sharply and significantly $(\mathrm{P}=0.008$ and $\mathrm{P}=0.003$, respectively) from $0.36 \pm 0.036$ to $0.65 \pm 0.066 \mu \mathrm{g} \mathrm{g}^{-1}$ and
$0.26 \pm 0.014$ to $0.46 \pm 0.039 \mu \mathrm{g} \mathrm{g}{ }^{-1}$, respectively, during the first $8 \mathrm{~h}$ of exposure to clean water (Fig. 4). Thereafter, they declined significantly $(\mathrm{P}=0.049)$ at 12 $\mathrm{h}$, fluctuated for the next $36 \mathrm{~h}$ before registering sharp and significant $(\mathrm{P}=0.007)$ decline at $72 \mathrm{~h}$. Endosulfan or its metabolites were not detected in the aquaria water during the elimination period.

\section{Tissue Partitioning}

Figure 5 shows that the partitioning of $\alpha$ - and $\beta$ endosulfan was highest in the gonads $(39.2 \pm 0.45$ and $22.2 \pm 0.28 \mu \mathrm{g} \mathrm{g} \mathrm{g}^{-1}$, respectively) $>$ liver $(10.9 \pm 0.02$ and $6.1 \pm 0.40 \mu \mathrm{g} \mathrm{g} \mathrm{g}^{-1}$, respectively) $>$ gut $(6.1 \pm 0.27$ and $4.6 \pm 0.07 \mu \mathrm{g} \mathrm{\textrm {g } ^ { - 1 }}$, respectively) $>$ gills $(2.5 \pm 0.42$ and $1.6 \pm 0.39 \mu \mathrm{g} \mathrm{g}^{-1}$, respectively) $>$ Skin, Muscles and Bones (SMB) (1.1 \pm 0.03 and $0.9 \pm 0.03 \mu \mathrm{g} \mathrm{g}^{-1}$, respectively). 


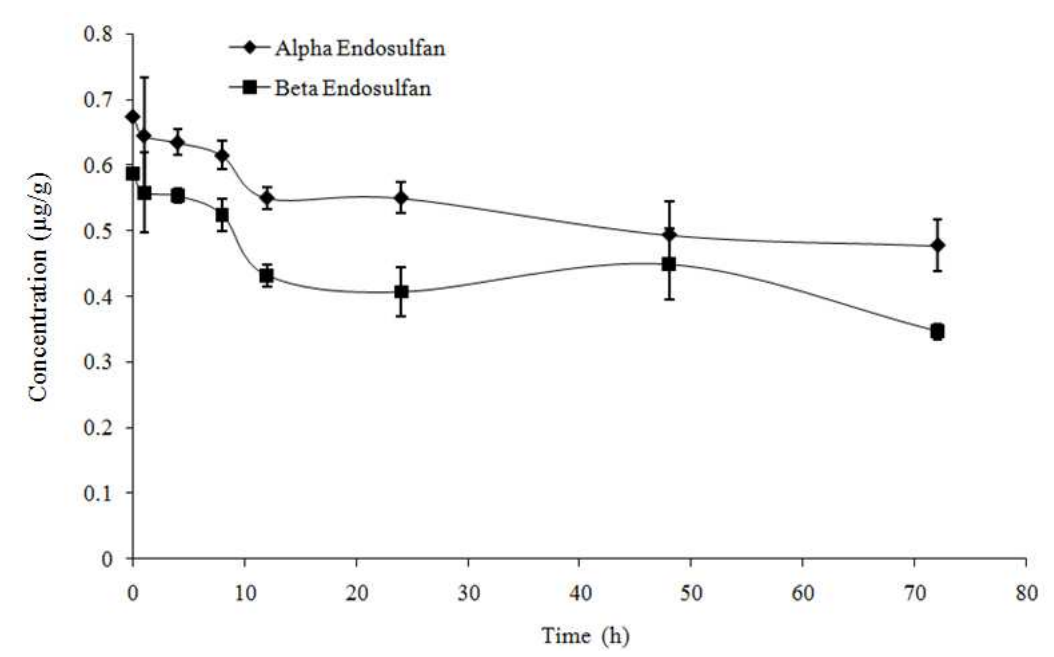

Fig. 3. The elimination of $\alpha$ - and $\beta$-endosulfan by Tilapia after 24 -h exposure to approximately $0.015 \mathrm{mg} \mathrm{L}^{-1}$ of endosulfan

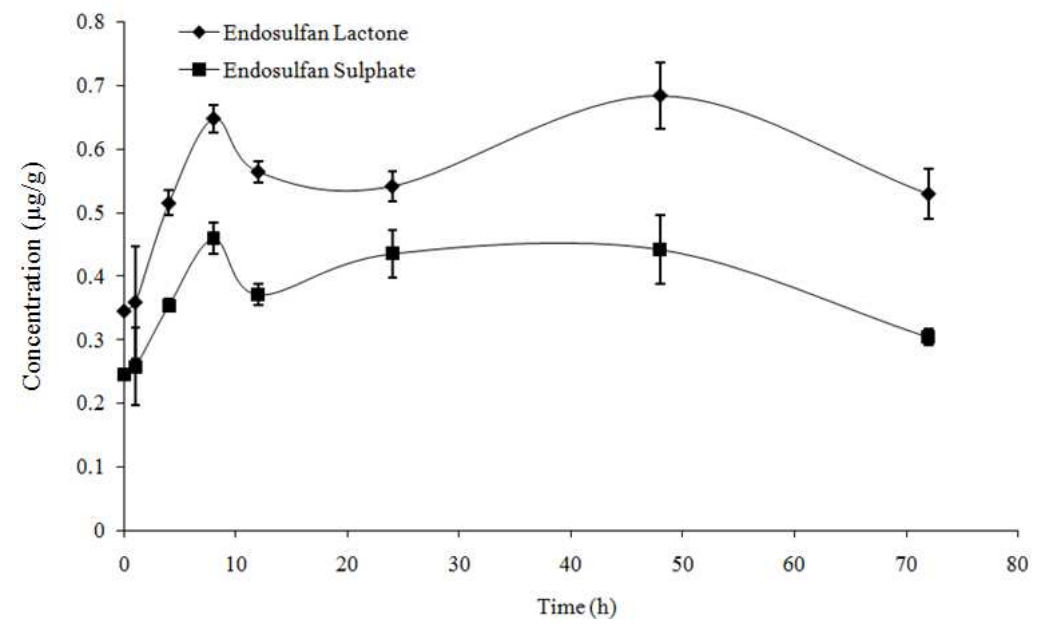

Fig. 4. The formation and elimination of endosulfan lactone and endosulfan sulphate by Tilapia after 24-h exposure to approximately $0.015 \mathrm{mg} \mathrm{L}^{-1}$ of endosulfan

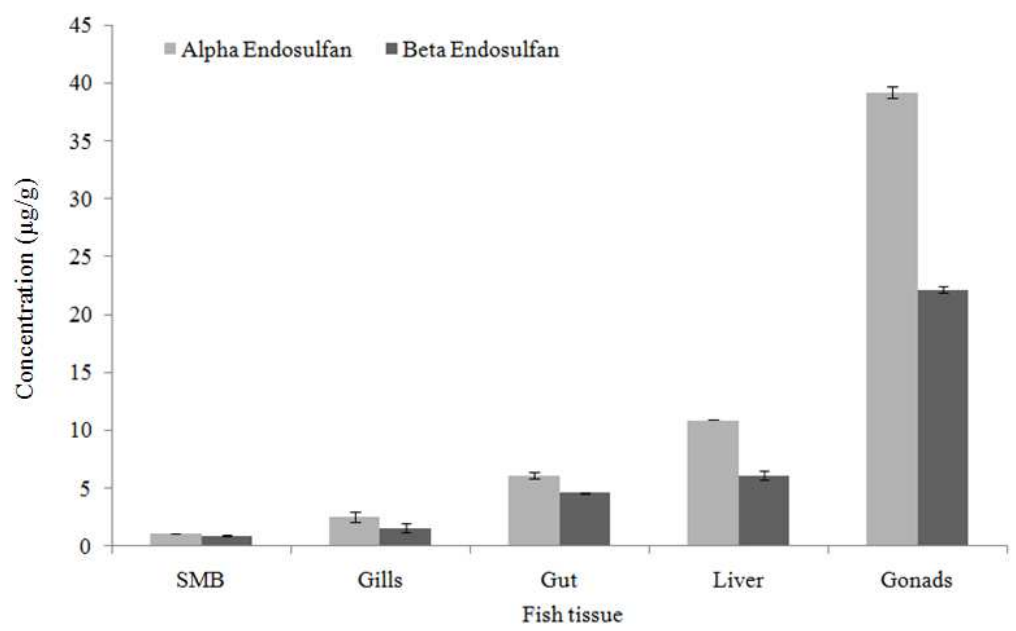

Fig. 5. The partitioning of accumulated $\alpha$ - and $\beta$-endosulfan in body tissues of Tilapia after 24 -h exposure to approximately 0.015 $\mathrm{mg} \mathrm{L}^{-1}$ of endosulfan 


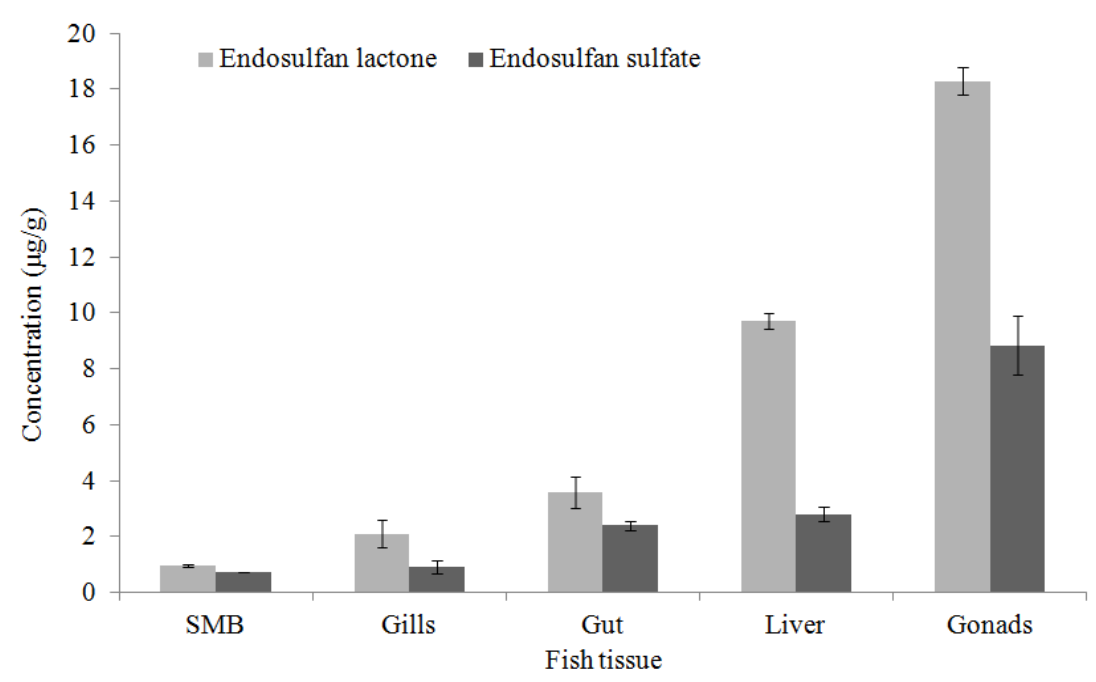

Fig. 6. The formation and partitioning of endosulfan lactone and endosulfan sulfate in body tissues of Tilapia after 24-h exposure to approximately $0.015 \mathrm{mg} \mathrm{L}^{-1}$ of endosulfan

Most of endosulfan lactone and sulfate were also partitioned in the gonads, $18.3 \pm 0.49$ and $8.84 \pm 1.06 \mu \mathrm{g}$ $\mathrm{g}^{-1}$, respectively, followed by liver, $9.7 \pm 0.28$ and $2.8 \pm 0.25 \mu \mathrm{g} \mathrm{g}^{-1}$, respectively $>$ gut, $3.6 \pm 0.56$ and $2.4 \pm 0.17 \mu \mathrm{g} \mathrm{g} \mathrm{g}^{-1}$, respectively $>$ gills, $2.1 \pm 0.48$ and $0.9 \pm 0.23 \mu \mathrm{g} \mathrm{g}^{-1}$, respectively $>\mathrm{SMB}, 0.97 \pm 0.03$ and $0.73 \pm 0.01 \mu \mathrm{g} \mathrm{g}^{-1}$, respectively (Fig. 6).

\section{Discussion}

The pattern of bioconcentration and elimination of endosulfan by tilapia was similar to that of different organophosphates (Tsuda et al., 1989) and PCBs (Smith et al., 1990) by other fish species and dieldrin by the shrimp, Macrobrachium faustinum (Robinson et al., 2002). The higher rate of uptake and elimination and tissue partitioning of $\alpha$ - than the $\beta$-isomer reflect the 7:3 ratio of the two in technical endosulfan (Goebel et al., 1982). The initial rapid bioconcentration within 1-4 $\mathrm{h}$ of exposure to $0.005 \mathrm{mg} \mathrm{L}^{-1}$ (Fig. 1) is a reflection of diffusion of the residues across the concentration gradient and the partition coefficient between the aqueous and organic (tissue) phases (Huckle and Milburn, 1990). Compounds like endosulfan, with low water solubility and high lipid solubility and log $\mathrm{K}_{\mathrm{OW}}$ values, tend to concentrate rapidly in organisms (Chiou et al., 1977; Mackay et al., 1992; Rand, 1995). The calculated Bioconcentration Factor (BCF) by tilapia is 93, which is very close to the critical figure of 100 proposed by Esser and Moser (1982).

The subsequent decline in the rate of bioconcentration reflects the process of bioaccumulation which involves the dynamic equilibrium between the uptake and degradation and elimination of the residues (Spacie et al., 1995). Metabolism of endosulfan to endosulfan lactone and sulfate did occur after a time-lag of at least an hour after the peak of bioconcentration (Fig. 2).

Elimination of residues from the body occurs along the concentration gradient (Branson et al., 1975) and depends upon their water solubility (Huckle and Millburn, 1990). It thus seems unlikely that any significant amount of unconverted endosulfan was eliminated during the bioconcentration process. Even when the contaminated fishes were exposed to clean water, elimination of endosulfan was quite slow; it rules out the possibility of passive or active elimination of the residues during the bioconcentration process. The accelerated conversion of endosulfan to lactone and sulfate metabolites by the fish in uncontaminated water (Fig. 4) suggests that enzymatic degradation of endosulfan to water-soluble metabolites is the main pathway for the elimination of residues from the body.

Partitioning of almost $66 \%$ of the residues in the gonads and $16 \%$ in liver confirms the pattern observed with dieldrin in various fishes (Westernhagen and Klumpp, 1995). In the mussel Mytilus edulis, however, partitioning of endosulfan was in gut $>$ gills $>$ foot + muscles $>$ gonads (Roberts, 1975). Biotransformation of residues occurs mainly in liver, though kidney, plasma, intestine and its microflora and brain may also be involved (Huckle and Milburn, 1990). Tilapia may thus be storing the metabolites of endosulfan in the other tissues (Fig. 6).

\section{Ecotoxicity Potential}

Residues of endosulfan in Jamaican rivers and coastal waters usually ranged between 0.001 and $33.0 \mu \mathrm{g} \mathrm{L}^{-1}$ (Mansingh et al., 1997) but may have been much higher after post-spraying rains in coffee plantations. The $t_{1 / 2}$ value of the residues of 87-548 days in river and coastal waters (Robinson et al., 1997) would ensure the 
persistence of undesirable contaminants in the environment for a relatively prolonged period. Furthermore, production of endosulfan sulfate within the tissues is not a detoxification process, as the metabolite is highly toxic to fishes (Goebel et al., 1982) but is more water soluble (Gopal et al., 1985) and can, therefore, be eliminated much more easily than its parent compound. The high level of residues in the gonads must have an adverse effect on tilapia's reproductive physiology since $0.0015 \mathrm{mg}$ $\mathrm{L}^{-1}$ of endosulfan was found to decrease plasma vitellogenins and induced developmental abnormality in the fry of the catfish (Chakravorty et al., 1992).

\section{Conclusion}

The data generated in the study indicate that endosulfan is rapidly taken up from surrounding water by the Tilapia fish and is eliminated at a much slower rate when they are exposed to clean water. This led to an accumulation of endosulfan residues in the tissues of the fish with the highest levels of accumulation occurring in the gonads of the fish. Endosulfan sulfate and endosulfan lactone were detected in the fish four hours after they were exposed to the parent compound, which may be an attempt by the fish to convert the pesticide to products which may be more easily eliminated from the body.

\section{Acknowledgement}

This study was supported by the Departments of Life Sciences and Chemistry, Faculty of Science and Technology, The University of the West Indies, Mona.

\section{Ethics}

This article is original and contains unpublished material. No breech of ethical procedures was involved in the research and preparation of this manuscript.

\section{References}

Branson, D.R., G.E. Blau, H.C. Alexander and W.B. Neely, 1975. Bioconcentration of 2,2',4,4'Tetrachlorobiphenyl in Rainbow Trout as Measured by an Accelerated Test. Trans. Am. Fish Soc., 104: 785-792. DOI: $\quad 10.1577 / 1548$ 8659(1975) $104<785$ :BOTIRT $>2.0$. CO;2

Chakravorty, S., B. Lal and T.P. Singh, 1992. Effect of endosulfan (thiodan) on vitellogenesis and its modulation by different hormones in the vitellogenic catfish clarias batrachus. Toxicology, 75: 191-198. PMID: 1455428

Chiou, C.T., V.H., Freed, D.W. Schmedding and R.L. Kohnert, 1977. Partition coefficient and bioaccumulation of selected organic chemicals. Environ. Sci. Technol., 11: 475-478.

DOI: $10.1021 / \mathrm{es} 60128 \mathrm{a} 001$
Chopra. A.K., M.K. Sharma and S. Chamoli, 2011. Bioaccumulation of organochlorine pesticides in aquatic system-an overview. Environ. Monit. Assess., 173: 905-916.

DOI: $10.1007 / \mathrm{s} 10661-010-1433-4$

Esser, H.O. and P. Moser, 1982. An appraisal of problems related to the measurement and evaluation of bioaccumulation. Ecotoxicol. Environ. Saf., 6: 131-148. DOI: 10.1016/0147-6513(82)90001-X

Goebel, H., S. Gorbach, W. Knauf, R.H. Rimpau and H. Huttenbach, 1982. Properties, effects, residues and analytics of the insecticide Endosulfan. Residue Rev., 83: 165-165. PMID: 6750730

Gopal, K., M. Anand, S. Mehrotra and P.K. Ray, 1985. Neurobehavioural changes in fresh water fish Channapunctatus exposed to endosulfan. J. Adv. Zool, 6: 74-80.

Huckle, K.R. and P. Millburn, 1990. Metabolism, Bioconcentration and Toxicity of Pesticides in Fish. In: Environmental Fate of Pesticides, Hudson, D.H. and T.R. Roberts, (Eds.), John Wiley and Sons. pp: 176-243.

Mackay, D., H. Puig and L.S. McCarty, 1992. An equation describing the time course and variability in uptake and toxicity of narcotic chemicals to fish. Environ. Toxicol. Chem., 11: 941-951. DOI: $10.1002 /$ etc. 5620110707

Mansingh, A., D.E. Robinson and K.M. Dalip, 2003. Use, Fate and Ecotoxicity of Pesticides in Jamaica and the Commonwealth Caribbean. In: Pesticide Residues in Coastal Tropical EcosystemsDistribution, Fate and Effects, Taylor, M.D., S.J. Klaine, F.P Carvalho, D. Barcelo and J. Everaarts (Eds.), Taylor and Francis, London and New York, pp: 426-463.

Mansingh, A., D.E. Robinson and K.M. Dalip, 1997. Insecticide contamination of the Jamaican environment. Trends Anal. Chem., 16: 115-123. DOI: $10.1016 / \mathrm{S} 0165-9936(97) 00006-X$

Rand, G.M., 1995. Fundamentals of Aquatic Toxicology: Effects, Environmental Fate and Risk Assessment. 2nd Edn., CRC Press, ISBN-10: 1560320907, pp: 1125.

Roberts, D., 1975. Differential uptake of endosulfan by the tissues of Mytilus edulis. Bull. Environ. Contam. Toxicol., 13: 170-176. DOI: 10.1007/BF01721732

Robinson, D.E. and A. Mansingh, 1999. Insecticide contamination of Jamaican environment. IV. transport of the residues coffee plantations in the blue mountains to coastal waters in eastern Jamaica. Environ. Monit. Assess., 54, 125-141. DOI: $10.1023 / \mathrm{A}: 1005806815959$

Robinson, D E., C. Henry and A. Mansingh, 2002. Toxicity, bioaccumulation and tissue partitioning of dieldrin by the shrimp, Macrobrachium faustinum de Sassure, in fresh and brackish waters of Jamaica. Environ. Technol., 23: 1275-1284. PMID: 12472158 
Robinson, D.E., A. Mansingh and T.P. Dasgupta, 1997. The fate of endosulfan in soil and soil and in river and coastal waters of Jamaica. Proceedings of the International Symposium on the Use of Nuclear and Related Techniques for Studying Environmental Behaviour of Crop Protection Chemicals, Jul. 1-5, IAEA, Vienna, pp: 301-311.

Shahpoury, P., K.J. Hageman, C.D. Matthaei and F.S. Magbanua, 2013. Chlorinated pesticides in stream sediments from organic, integrated and conventional farms. Environ. Pollut., 181: 219-225. DOI: 10.1016/j.envpol.2013.06.035

Singh, N.C., T.P. Dasgupta, E.V. Roberts and A. Mansingh, 1991. Dynamics of pesticides in tropical conditions. 1. Kinetic studies of volatilization, hydrolysis and photolysis of dieldrin and .alpha.- and .ß.-endosulfan. J. Agric. Food Chem., 39: 575-579. DOI: $10.1021 /$ jf00003a028

Smith, A.D., A. Bharath, C. Mallard, D. Orr and L.S. McCarty et al., 1990. Bioconcentration kinetics of some chlorinated benzenes and chlorinated phenols in American flagfish, Jordanella floridae (Goode and Bean). Chemosphere, 20: 379-386.

DOI: $10.1016 / 0045-6535(90) 90068-5$
Spacie, A., L.S. McCarty and G.M. Rand, 1995. Bioaccumulation and Bioavailability in Multiphase Systems. In: Fundamentals of Aquatic Toxicology: Effects, Environmental Fate and Risk Assessment, Rand, G.M. (Ed.), Taylor and Francis; Wash., D.C., USA.

Tsuda, T., S. Aoki, M. Kojima and H. Harada, 1989. Bioconcentration and excretion of diazinon, IBP, malathion and fenitrothion by Willow Shiner. Toxicol. Environ. Chem., 24: 185-190. DOI: $10.1080 / 02772248909357489$

Westernhagen, H. von and D.W. Klumpp, 1995. Organochlorine residues above limits of detection in fish from the marine environment of tropical Queensland, Australia. Marine Poll. Bull., 30: 166-169.

Witter, J.V., D.E. Robinson, A. Mansingh and K.M. Dalip, 1999. Insecticide contamination of Jamaican environment. V. island-wide rapid survey of residues in surface and ground water. Environ. Monitor. Assess., 56: 257-267.

DOI: $10.1023 / \mathrm{A}: 1005959704697$ 